\title{
PENDIDIKAN HUMANISTIK KI HAJAR DEWANTARA DALAM PERSPEKTIF PENDIDIKAN ISLAM
}

\author{
Budiono \\ Program Pascasarjana Institute Agama Islam Tribakti Kediri
}

\begin{abstract}
Abstrak
Upaya untuk memperbaiki moralitas bangsa yang kian merosot terus dilakukan salah satunya dengan mengimplementasikan pendidikan karakter dalam tiap jenjang pendidikan. Namun tentu bukan hal yang mudah untuk melakukannya apalagi menikmati hasilnya dalam waktu yang singkat. Berbagai permasalahan yang bersangkutan dengan akhlak mulai mencuat hingga menyebabkan degradasi moral. Diperlukan alternatif untuk mendukung upaya perbaikan moralitas bangsa Karenanya, perlu kajian mengenai pendidikan karakter yang diharapkan mampu memberikan pencerahan.

Tesis ini merupakan penelitian kepustakaan (library reseach) yang membicarakan pendidikan karakter. Selain itu, tesis ini juga meneliti tentang konsep Humanis pendidikan karakter menurut Ki Hadjar Dewantara dalam Perspektif Pendidikan Agama Islam.

Adapun pokok- pokok pikirannya yang mengkaji beberapa hal diatas adalah sebagai berikut: Tujuan pendidikan menurut Ki Hajar Dewantara adalah memanusiawikan manusia (humanisasi), pendidikan adalah daya upaya untuk memajukan budi pekerti, pikiran, dan jasmani anak agar selaras dengan alam dan masyarakatnya. Pembentukan budi pekerti yang baik harus dilakukan mulai dari lingkungan keluarga, lingkungan sekolah serta lingkungan masyarakat, sehingga ada kesinambungan antara keluarga, sekolah dan masyarakat. Sedangkan Pendidikan Islam tujuan pendidikan berorientasi pada pembinaan akhlak yang holistik yakni akhlak yang menyeluruh, meliputi akhlak kepada Allah Swt (habl min Allah), diri sendiri dan orang lain (habl min al-nas).
\end{abstract}

Kata Kunci: Pendidikan Humanis, Pendidikan Akhlak, dan Pendidikan Karakter.

\section{A. Konteks Kajian}

Pendidikan merupakan suatu proses di dalam menemukan transformasi baik dalam diri, maupun komunitas. Oleh sebab itu, proses pendidikan yang benar hendaknya membebaskan seseorang dari berbagai kungkungan, intimidasi, dan eksploitasi. Disinilah letak afinitas dari pedagogik, yaitu membebaskan manusia secara komprehensif dari ikatan-ikatan yang terdapat diluar dirinya atau dikatakan sebagai sesuatu yang mengikat kebebasan seseorang.

Menurut Ki Hajar Dewantara, anak didik adalah makhluk bebas yang memiliki alamnya sendiri sehingga mereka tidak seharusnya diperlakuakan seperti robot atau mainan yang bisa dipermainkan secara manipulatif. Anakanak didik adalah makhluk yang memiliki nasib dan masa depan pendidikan masingmasing sehingga peran seorang pendidik dalam pendidikan adalah mengarahkan mereka sesuai dengan potensi dan bakat yang dimilikinya. Dengan kata lain, anak didik adalah makhluk yang dilahirkan sebagai sosok-sosok dengan kebebasan dan kemerdekaan untuk mewujudkan eksistensi dirinya secara terbuka dan mandiri. Mereka mengaktualisasikan segala potensi dan bakatnya dengan mandiri dan terbuka pula. ${ }^{1}$

1 . Moh. Yamin. Menggugat Pendidikan Indonesia, Belajar dari Paulo Freire dan Ki Hadjar Dewantara, (Jogjakarta: Ar-Ruzz Media, 2009), hlm. 159. 
Ki Hadjar Dewantara yang mengusung teori pendidikan nasional, dengan konsep penguatan penanaman nilai-nilai luhur yang dimiliki oleh bangsa sendiri secara masif dalam kehidupan anak didik. Sebagaimana yang diungkapkan oleh Ki Hadjar Dewantara yang dikutip Mohammad Yamin dalam sebuah penggambaran proses humanisasi;

"Berilah kemerdakaan kepada anak-anak didik kita: bukan kemerdekaan yang leluasa, tetapi yang terbatas oleh tuntutan-tuntutan kodrat alam yang nyata dan menuju ke arah menyelamatkan dan membahagiakan hidup dan penghidupan diri dan masyarakat, maka perlulah dipakai dasar kebangsaan, tetapi jangan sekali-kali dasar ini melanggar atau bertentangan dengan dasar yang lebih luas yaitu dasar kemanusiaan".

Jika ditinjau dari pendidikan Islam metode dalam pendidikan yang digunakan yang sama dengan among metode atau konsep Tut Wuri Handayani antara lain: metode teladan, metode kisah, metode nasehat, metode targhib dan tarhid.

Dari penjelasan di atas dapat disimpulkan bahwa pendidikan humanistik dalam pandangan Ki Hajar Dewantara sesuai dengan pandangan Islam. Terutama dalam budi pekerti yang dalam Islam biasa disebut dengan akhlak. Karena humanisme dalam Islam didasarkan pada hubungan sesama umat manusia yang membutuhkan pendidikan akhlak atau budi pekerti sehingga seseorang menjadi manusia yang dapat menghormati dan menghargai manusia lainnya.

Dari sinilah penulis mengadakan penelitian pustaka dengan judul

"Pendidikan Humanistik Ki Hajar Dewantara dalam Perspektif Pendidikan Islam”.

\section{B. Fokus Kajian}

Berdasarkan latar belakang yang telah dipaparkan di atas dapat diambil rumusan masalah sebagai berikut: 1) Bagaimana konsep pendidikan humanistik Ki Hadjar Dewantara. 2) Bagaimana perbandingan dan relevansi konsep pendidikan humanistik $\mathrm{Ki}$ Hadjar Dewantara dengan Pendidikan AgamaIslam,
3) Apa fungsi pendidikan humanistic dalam system pendidikan nasional?

\section{Pendidikan Humanis}

Dewasa ini pemerintah sedang menggalakkan pentingnya pendidikan berkarakter, yang sebenarnya bapak pendidikan Indonesia Ki Hadjar Dewantara sudah sejak dahulu kala mencanangkan konsep pendidikan berkarakter yang kita kenal sekarang dengan pendidikan humanis. Pendek kata sebenarnya pendidikan humanis ala Ki Hajar Dewantara dengan pendidikan karakter seperti dua keping mata uang, atau hampir persis sama. Pendidikan humanis berasal dari dua kata pendidikan dan humanis, menurut beberapa ahli, kata pendidikan mempunyai definisi yang berbeda-beda tergantung pada sudut pandang, paradigma, metodologi dan disiplin keilmuan yang digunakan, diantaranya: Menurut D. Rimba, pendidikan adalah "Bimbingan atau pembinaan secara sadar oleh pendidik terhadap perkembangan Jasmani dan Rohani anak didik menuju terbentuknya kepribadian yang utuh. ${ }^{2}$

Kamus Bahasa Indonesia kata 'karakter' diartikan sebagai tabiat, sifat-sifat kejiwaan, akhlak atau budi pekerti yang membedakan seseorang dangan yang lain, dan watak. Ki Hadjar Dewantara memandang karakter sebagai inti pendidikan humanis sebagai watak atau budi pekerti. Menurutnya budi pekerti adalah bersatunya antara gerak fikiran, perasaan, dan kehendak atau kemauan yang kemudian menimbulkan tenaga.

Dari beberapa definisi karakter tersebut dapat disimpulkan secara ringkas bahwa karakter adalah sikap, tabiat, akhlak, kepribadian yang stabil sebagai hasil proses konsolidasi secara progresif dan dinamis; sifat alami seseorang dalam merespons siruasi secara bermoral; watak, tabiat, akhlak, atau kepribadian seseorang yang terbentuk dari hasil internalisasi berbgai kebajikan, yang diyakini dan digunakan sebagai landasan untuk cara pandang, berpikir, bersikap dan bertindak; sifatnya jiwa manusia, mulai dari angan-angan sampai menjelma menjadi tenaga.mengenai

2 D. Marimba, Pengantar Filsafat Pendidikan Islam, (Bandung: Al-Ma'arif, 1989), h. 19. 
sesuatu yang ada dalam diri seseorang, yang membuat orang tersebut disifati.

Menurut Ramli, pendidikan karakter memiliki esensi dan makna yang sama dengan pendidikan moral dan pendidikan akhlak. Tujuannya adalah membentuk pribadi anak, supaya menjadi manusia yang baik, warga masyarakat yang baik dan warga Negara yang baik. Adapun kriteria manusia yang baik, warga masyarakat yang baik, dan warga Negara yang baik bagi suatu masyarakat atau bangsa, secara umum adalah nilai-nilai sosial tertentuyang banyak dipengaruhi oleh budaya masyarakat dan bangsanya. Oleh karena itu, hakikat pendidikan karakter dalam konteks pendidikan Indonesia adalah pendidikan nilai, yakni pendidikan nilai-nilai luhur yang bersumber dari budaya bangsa Indonesia sendiri, dalam rangka membina kepribadian generasi muda. ${ }^{3}$

Pendidikan humanis juga dapat dimaknai sebagai upaya yang terencana untuk menjadikan peserta didik mengenal, peduli, dan menginternalisasikan nilai-nilai sehingga peserta didik menjadi insan kamil. Pendidikan humanis juga dapat diartikan sebagai suatu system penanaman nilai-nilai karakter kepada warga sekolah yang meliputi komponen pengetahuan, kesadaran atau kemauan dan tindakan untuk melaksanakan nilai-nilai tersebut baik terhadap Tuhan Yang Maha Esa, diri sendiri, sesana, lingkungan maupun kebangsaan sehingga menjadi manusia yang sempurna.

Pendidikan humanis adalah proses menanamkan karakter tertentu sekaligus memberi benih agar peserta didik mampu menumbuhkan karakter khasnya pada saat menjalankan kehidupan. Dengan kata lain, peserta didik tidak hanya memahami pendidikan sebagai bentuk pengetahuan, namun juga menjadikan sebagai bagian dari hidup dan secara sadar hidup berdasarkan pada nilai tersebut.

\section{B. Tujuan Pendidikan Humanistik}

Pada dasarnya Pendidikan sebagaimana

3 Heri Gunawan, Pendidikan Karakter Konsep dan Implementasi, (Bandung:Alfabeta, 2012) , h.23 digariskan Ki Hajar Dewantara bertujuan untuk meningkatkan mutu penyelenggaraan dan hasil pendidikan yang mengarah pada pencapaian pembentukan karakter atau akhlak mulia peserta didik secara utuh, terpadu, dan seimbang, sesuai standar kompetensi lulusan. Melalui pendidikan karakter diharapkan peserta didik mampu secara mandiri meningkatkan dan menggunakan pengetahuannya, mengkaji dan menginternalisasi serta mempersonalisasi nilai-nilai karakter dan akhlak mulia sehingga terwujud dalam perilaku sehari-hari. ${ }^{4}$

Hal ini sesuai dengan rumusan tujuan pendidikan nasional yang terdapat pada UUSPN No.20 tahun 2003 Bab 2 pasal 3: Pendidikan Nasional berfungsi mengembangkan kemampuan dan membentuk watak serta peradaban bangsa yang bermartabat dalam rangka mencerdaskan kehidupan bangsa, bertujuan untuk berkembangnya potensi anak didik agar menjadi manusia yang beriman dan bertakwa kepada Tuhan Yang Maha Esa, berakhlak mulia, sehat, berilmu, cakap, kreatif, mandiri, dan menjadi warga negara yang demokratis serta bertanggung jawab. ${ }^{5}$

Oleh karena itu diperlukan cara yang baik dalam membangun karakter seseorang. Salah satu cara yang sangat baik adalah dengan menciptakan lingkungan yang kondusif. Untuk itu peran keluarga, sekolah dan komunitas amat sangat menentukan pembangunan karakter anak-anak untuk kehidupan yang lebih baik di masa mendatang. ${ }^{6}$

\section{Konsep Humanis sebagai inti Pendidikan Karakter dalam Kurikulum 2013}

Pada saat ini yang diperlukan adalah kurikulum pendidikan yang berbasis karakter; hal ini kemudian dijawab pemerintah melalui Kemendikbud dengan mengimplementasikan kurikulum 2013 pada 15 juli 2013.

4 http://aryforniawan.blogspot.com/2016/06/fungsi-dantujuan-pendidikan-karakter.html

5 Dharma Kesuma, et.al, Pendidikan Karakter Kajian Teori dan Praktik di Sekolah (Bandung: Remaja Rosdakarya, 2011), h. 6.

6 Zainul Miftah, Implementasi Pendidikan Karakter Melalui Bimbingan dan Konseling, (Surabaya: Gena Pratama Pustaka,2011), 37. 
Konsep pendidikan karakter pada kurikulum 2013 bisa dilihat dari penyusunan kompetensi inti yang kemudian menjadi acuan untuk membuat kompetensi dasar. Berikut adalah contoh Kompetensi inti yang digunakan dalam kurikulum 2013 pada mata pelajaran Pendidikan Agama Islam di kelas VII:

1. Menghargai dan menghayati ajaran agama yang dianutnya. Merupakan bentuk dan manifestasi karakter religius

2. Menghargai dan menghayati perilaku jujur, disiplin, tanggungjawab, peduli (toleransi, gotong royong), santun, percaya diri dalam berinteraksi secara efektif dengan lingkungan sosial dan alam dalam jangkauan pergaulan dan keberadaannya.

3. Memahami pengetahuan (faktual, konseptual dan procedural) berdasarkan rasa ingin tahunya tentang ilmu pengetahuan, teknologi, seni, budaya terkait fenomena dan kejadian tampak mata

4. Mencoba, mengolah, dan menyaji dalam ranah konkret (menggunakan, mengurai, merangkai, memodifikasi, dan membuat) dan ranah abstrak (menulis, membaca, menghitung, menggambar, dan mengarang) sesuai dengan yang dipelajari di sekolah dan sumber lain yang sama dalam sudut pandang/teori.

Dari kompetensi inti tersebut bahwa kurikulum 2013 memang memberikan penekanan khusus pada pendidikan karakter.

\section{Nilai-nilai Humanis Dalam Pendidikan Karakter}

Pendidikan karakter berpijak dari karakter dasar manusia, yang bersumber dari nilai moral universal (bersifat absolut) yang bersumber dari agama yang juga disebut sebagai the golden rule. Pendidikan karakter dapat memiliki tujuan yang pasti, apabila berpijak dari nilainilai karakter dasar tersebut.

Menurut para ahli psikolog, beberapa nilai karakter dasar tersebut adalah: cinta kepada Allah dan ciptaan-Nya (alam dengan isinya), tanggung jawab, jujur, hormat dan santun, kasih sayang, peduli, dan kerjasama, percaya diri, kreatif, kerja keras, dan pantang menyerah, keadilan dan kepemimpinan; baik dan rendah hati, toleransi, cinta damai, dan cinta persatuan.

Pendidikan karakter dianggap sebagai pendidikan nilai moralitas manusia yang disadari dan dilakukan dalam tindakan nyata. Tampak di sini terdapat unsur pembentukan nilai tersebut dan sikap yang didasari pada pengetahuan untuk melakukannya. Nilai-nilai itu merupakan nilai yang dapat membantu interaksi bersama orang lain secara lebih baik (learning to live together). Nilai tersebut mencakup berbagai bidang kehidupan, seperti hubungan dengan sesama (orang lain, keluarga), diri sendiri (learning to be), hidup bernegara, lingkungan dan Tuhan. ${ }^{7}$ Tentu saja dalam penanaman nilai tersebut membutuhkan tiga aspek, baik kognitif, afektif maupun psikomotorik.

Senada dengan yang diungkapkan oleh Lickona $^{8}$, yang menekankan tiga komponen karakter yang baik, yaitu moral knowing (pengetahuan tentang moral), moral feeling (perasaan tentang moral), dan moral action (perbuatan moral).Sehingga dengan komponen tersebut, seseorang diharapkan mampu memahami, merasakan dan mengerjakan nilai-

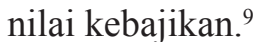

7 . Masnur Muslih, Pendidikan Karakter Menjawab Tantangan Krisis Multidimensional (Jakarta; Bumi Aksara, 2011), 67.

8 .Lickona bernama lengkap Thomas Lickona, merupakan salah satu tokoh pemikir pendidikan karakter kontemporer. la memiliki pandangan, bahwa terjadi dikotomi antara pendidikan karakter dan pendidikan agama. Keduanya seharusnya dipisahkan dan tidak dicampuradukkan. Baginya, nilai dasar harus dihayati jika masyarakat masih mau hidup dan bekerja secara damai. Nilai-nilai yang seharusnya diprioritaskan dalam pendidikan karakter adalah nilai kebijaksanaan, penghormatan terhadap yang lain, tanggung jawab pribadi, perasaan senasib sependeritaan (public compassion), pemecah konflik secara damai. Lebih lanjut, menurutnya agama bukan menjadi urusan sekolah negeri (public school). Sedangkan pendidikan karakter tidak ada relevansinya dengan ibadah dan doa-doa yang dilakukan dalam lingkungan sekolah. Agama memiliki hubungan vertikal antara sorang pribadi dengan keilahian, sedangkan pola pendidikan karakter adalah horisontal di dalam masyarakat, antara individu satu dengan yang lain. Lihat, Abdul Majid, Pendidikan Karakter Persfektif Islam (Bandung: Remaja Rosdakarya, 2011), 61-62

9 . Muslih, Pendidikan Karakter, 75. 


\section{E. Konsep Pendidikan Humanis pada Pendidikan Akhlak dalam Islam}

Pendidikan Akhlak, mengenai penjelasan akhlak secara luas, banyak sekali tokoh yang memberikan pengertian secara bervariasi. Diantaranya M. Abdullah Darraz, menurut beliau akhlak adalah sesuatu kekuatan dalam kehendak yang mantap, kekuatan dan kehendak mana berkombinasi membawa kecenderungan pada pemilihan pihak yang benar (akhlak yang baik) atau pihak yang jahat (akhlak yang jahat). ${ }^{10}$

Akhlak dipahami oleh banyak pakar dalam arti "kondisi kejiwaan yang menjadikan pemiliknya melakukan sesuatu secara mudah, tidak memaksakan diri, bahkan melakukannya secara otomatis." Apa yang dilakukan bias merupakan sesuatu yang baik, dan ketika itu ia dinilai memiliki akhlak karimah/mulia/ terpuji, dan bisa juga sebaliknya, dan ketika itu ia dinilaimenyandang akhlak yang buruk. Baik dan buruk tersebut berdasar nilai-nilai yang dianut oleh masyarakat dimana yang bersangkutan berada.

Bentuk jamak pada kata akhlak mengisyaratkan banyak hal yang dicakup olehnya. Secara garis besar dapat dikatakan bahwa ia bukan saja aktifitas yang berkaitan dengan hubungan antar manusia tetapi juga hubungan manusia dengan Allah, dengan lingkungan. Baik lingkungan maupun bukan, serta hubungan diri manusia secara pribadi. Di samping itu juga perlu diingat bahwa Islam tidak hanya menuntut pemeluknya untuk bersikap baik terhadap pihak lain dalam bentuk lahiriah, sebagaimana yang ditekankan oleh sementara moralis dalam hubungan antar-manusia, tetapi Islam menekankan perlunya sikap lahiriah itu sesuai dengan sikap batiniah. Hadits nabi yang berkaitan dengan konsep pendidikan karakter adalah hadits

yang diriwayatkan oleh imam BukhariMuslim sebagai berikut:

10 . Erwin Yudi Prahara, Materi Pendidikan Agama Islam (Ponorogo: STAIN Po Press, 2009), 182.

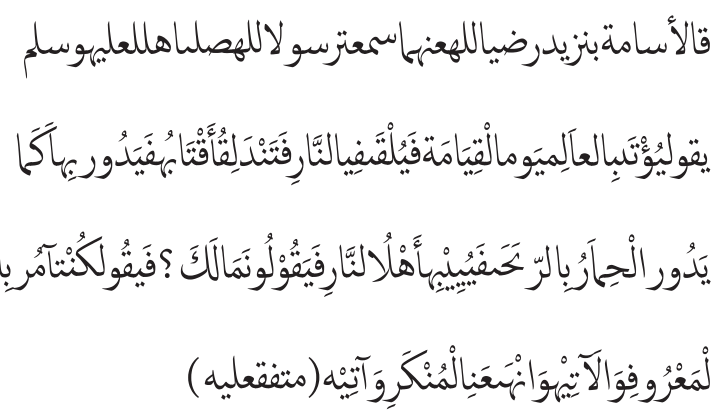

Artinya: "Usamah bin Zaid ra. berkata: Saya mendengar Rasulullah saw. bersabda: Akan dihadapkan orang yang berilmu pada hari kiamat, lalu keluarlah semua isi perutnya, lalu ia berputar-putar dengannya, sebagaimana himar yang ber-putar-putar mengelilingi tempat tambatannya. Lalu penghuni neraka disuruh mengelilinginya seraya bertanya: Apakah yang menimpamu? Dia menjawab: Saya pernah menyuruh orang pada kebaikan, tetapi saya sendiri tidak mengerjakan-nya, dan saya mencegah orang dari kejahatan, tetapi saya sendiri yang mengerjakannya". (Muttafaq Alaih) $^{11}$.

Dalam hadits riwayat Bukhori-Muslim di atas menguraikan bahwa pembentukan karakter yang didasari keteladanan akan menuai kebaikan bagi dirinya sendiri dan orang lain.

Dengan demikian, bila sejauh ini pendidikan karakter telah berhasil dirumuskan oleh para penggiat sampai pada tahapan yang sangat operasional meliputi metode, strategi, dan teknik, sedangkan pendidikan akhlak sarat dengan informasi kriteria ideal dan sumber karakter baik, maka memadukan keduanya menjadi suatu tawaran yang sangat inspiratif. Hal ini menjadi entry point bahwa pendidikan karakter memiliki ikatan yang kuat dalam nilainilai spiritualitas dan agama ${ }^{12}$.

11 . Abubakar Muhammad, Hadits Tarbawi III, (Surabaya: Karya Abditama, 1997), hlm. 70.

12 . Marfu', Perbedaan pendidikan karakter dengan pendidikan akhlak, pendidikan moral, danpendidikan nilai, http:// risetpendidikangmarfu'.com, Diakses pada tanggal29 agustus 2016 . 


\section{Latar belakang kehidupan dan kondisi sosial Ki Hadjar Dewantara}

Ki Hadjar Dewantara yang dikenal sebagai sosok pahlawan nasional, dengan segudang prestasi dan pemikiran yang di torehkannya maka sudah sepatutnya beliau di anugerahi gelar sebagai pahlawan nasional oleh bangsa ini.

Ki Hadjar Dewantara dilahirkan di Yogyakarta pada tanggal 2 Mei 1889. Beliau adalah putra kelima dari Soeryaningrat putra Paku Alam III. Pada waktu dilahirkan diberi nama Soewardi Soeryaningrat, karena beliau masih keturunan bangsawan maka mendapat gelar Raden Mas (RM) yang kemudian nama lengkapnya menjadi Raden Mas Soewardi Soeryaningrat. ${ }^{13}$

Bersama dengan Tjipto Mangunkusumo pada permulaan Juli 1913 membentuk "Committee tot Herdenking van Nederlandsch HonderdjarigeVrijheid" (panitia peringatan 100 tahun kemerdekaan Nederland) yang dalambahasa Indonesia disingkat "Komisi Bumi Putra". Panitia bermaksud akan mengeluarkan isi hati rakyat, memprotes adanya perayaan kemerdekaan Belanda karena rakyat Indonesia dipaksa secara halus harus memungut uang sampai ke pelosok-pelosok

Dengan tersebarnya tulisan tersebut, pemerintah Belanda menjadi marah. Kemudian Belanda memanggil panitia De Express untuk diperiksa. Dalam suasana seperti itu Cipto Mangunkusumo menulis dalam harian De Express 26 Juli 1913 untuk menyerang Belanda, yang berjudul "Kracht of Vress" (Kekuatan atau Ketakutan). Selanjutnya Soewardi Soeryanigrat kembali menulis dalam harian De Express tanggal 28 Juli 1913 yang berjudul "Een Voor Allen, Maar Ook Allen Voor Een " (Satu buat semua, tetapi juga semua buat satu). ${ }^{14}$

Setelah berbagai keadaan yang di pelajari Ki Hadjar Dewantara, bagi Ki Hadjar Dewantara

13 . Darsiti Soeratman, Ki Hadjar Dewantara, Jakarta. Departemen dan Kebudayaan 1983/1984. h. 8-9.

14 . Moch. Tauhid, Perjuangan dan ajaran Hidup Ki Hadjar Dewantara, (Yogyakarta, MLPTS,1963), h. 299. indonesia harus segera mempersiapkan konsep pendidikan nasional bagi seluruh rakyat Indonesia supaya rakyat tahu akan nasibnya sendiri dan mudah bersatu untuk mendapatkan suatu kemerdekaan.

Ki Hadjar Dewantara berpendapat bahwa kemerdekaan nusa dan bangsa untuk mengejar keselamatan dan kesejahteraan rakyat tidak hanya dicapai melalui jalan politik, tetapi juga melalui pendidikan. Oleh karenanya timbullah gagasan untuk mendirikan sekolah mandiri yang akan dibina sesuai dengan cita-citanya.

Untuk merealisasikan tujuannya, Ki Hadjar Dewantara mendirikan perguruan Taman Siswa. Cita-cita perguruan tersebut adalah "Saka" ("saka" adalah singkatan dari "Paguyuban Selasa Kliwonan" di Yogyakarta), dibawah pimpinan Ki Ageng Sutatmo Suryokusumo. Paguyuban ini merupakan cikal bakal perguruan Taman Siswa yang didirikan oleh Ki Hadjar Dewantara di Yogyakarta. Yakni: mengayu-ayu sarira (membahagiakan diri), mengayu-ayu bangsa (membahagiakan bangsa) dan mengayu-ayu manungsa (membahagiakan manusia).

3. Konsep Pendidikan Humanis dalam pendidikan Berkarakter Menurut Ki Hadjar Dewantara

a. Konsep Humanis sebagai Dasar Pendidikan Karakter

Untuk mewujudkan gagasannya tentang pendidikan yang dicitacitakan, dalam pelaksanaan pendidikan, Ki Hadjar Dewantara menggunakan "Sistem Among" sebagai perwujudan konsepsi beliau dalam menempatkan anak sebagai sentral proses pendidikan. Dalam Sistem Among, maka setiap guru (pamong) sebagai pemimpin dalam proses pendidikan diwajibkan bersikap:

Ing Ngarsa Sung Tuladha, Ing Madya Mangun Karsa, Tutwuri Handayani.Tiga semboyan inilah yang dijadikan sebagai konsep dasar pendidikan karakter.

1) Ing Ngarsa Sung Tuladha

Ing ngarsa berarti 'di depan' atau 'di muka'. Sun berasal dari kataingsun yang berarti 
'saya'. Tulodo berarti 'teladan'. Jadi ing ngarsasung tuladha mengandung makna, seorang pamong atau pendidikharusmampu memberikan suri teladan bagi anak didiknya.

Pendidik sebagai seorang pemimpin, maka ia harus memiliki sikap dan perilaku yang baik di segala langkah dan tindakannya agar dapat dijadikan dapat dijadikan sebagai "central figure" bagi siswa.

\section{2) Ing Madya Mangun Karsa}

Ingmadya berarti 'di tengah-tengah', mbangun berarti 'membangkitkan' atau 'menggugah', sedangkan karso diartikan sebagai 'bentuk kemauan' atau 'niat'. Jadi ing madya mangun karsa mengandung makna bahwa seorang pemimpin ditengan kesibukannya harus mampu membangkitkan atau menggugah semangat kerja anggota bawahannya.

Oleh karenanya, seorang pamong atau pendidik sebagai pemimpinhendaknya mampu menumbuh-kembangkan minat, hasrat dan kemauan anak didik untuk dapat kreatif dan berkarya, guna mengabdikan diri kepada citacita yang luhur dan ideal.

\section{3) Tutwuri Handayani}

Tutwuri berarti 'mengikuti dari belakang' Sedangkan handayani berarti 'memberikan dorongan moral atau dorongan semangat'. Jadi Tutwuri Handayani berarti seorang pendidik adalah pemimpin yangharus memberikan dorongan moral dan semangat kerja dari belakang.

Ki Hadjar Dewantara menjelaskan lebih jauh dan detail bahwa anak didik mencari jalan sendiri selama mereka mampu dan bisa melakukan itu karena ini merupakan bagian dari pendidikan pendewasaan diri yang baik dan membangun. Kemajuan anak didik, dengan membiarkan hal seperti itu, akan menjadi sebuah kemajuan sejati dan hakiki. Namun, kendatipun begitu, biarkan mereka berjalan sendiri, bukan berarti tidak diperhatikan dan dipedulikan, pendidik harus mengawasi kemanakah mereka akan menempuh jalan. Pendidik hanya mengamati, memberi teguran, maupun arahan ketika mengambil jalan yang salah dan keliru. Ini sesungguhnya yang dimaksud. Arahan dan teguran akan datang ketika anak didiknya akan tergelincir ke jalan yang tidak baik.

\section{b. Materi Pendidikan Karakter}

Materi pendidikan merupakan perencanaan yang dihubungkan dengan kegiatan pendidikan (belajar mengajar) untuk mencapai sejumlah tujuan. ${ }^{15}$ Oleh karena itu materi pendidikan karakter harus mengacu pada tujuan yang telah ditetapkan sehingga materi pendidikan karakter tidak boleh berdiri sendiri dan terlepas dari kontrol tujuannya. Di samping itu materi pendidikan karakter harus terorganisir secara rapi dan sistematis, sehingga dapat memudahkan tujuan yang dicitacitakan.

Dalam pelaksanaan pendidikan karakter menurut Ki Hadjar Dewantara haruslah sesuai dengan tingkatan umur para peserta didik. Hal ini dikarenakan seorang guru harus memahami tentang kondisi psikis dari peserta didik dengan tujuan bahwa ketika materi pendidikan karakter disampaikan harus dapat dipahami dan dicerna secara utuh. Sehingga Ki Hadjar membagi empat tingkatan dalam pengajaran pendidikan karakter, adapun materi pendidikan karakter tersebut adalah sebagai berikut:

\section{1) Taman Indria dan Taman Anak (5-8 tahun)}

Pada tingkatan ini materi atau isi pendidikan karakter (budi pekerti) berupa pengajaran pembiasaan yang bersifat global dan spontan atau occasional. ${ }^{16}$ Artinya materi yang disampaikan bukan teori yang berhubungan dengan kebaikan dan keburukan melainkan bagaiamana peserta didik dapat mengetahui kebaikan dan keburukan melalui tingkah laku dari peserta didik itu sendiri.

Materi pengajaran karakter bagi anak yang masih di sekolah ini berupa, latihan

15 . M. Ahmad, dkk.,Pengembangan Kurikulum, ( Bandung : Pustaka Setia, 1998 ), h. 10.

16 . Ki Hajar Dewantara, Bagian I Pendidikan, Ibid. h. 487. 
mengarah pada kebaikan yang memenuhi syarat bebas yaitu sesuai kodrat hidup anak. Materi ini dapat dilaksanakan melaui peran pendidik dalam membimbing, membina dan mengoreksi tingkah- laku dari masing-masing peserta didiknya. Sebagai contoh dalam pengajaran karakter tersebut, yaitu berupa anjuran atau perintah antara lain: ayo, duduk yang baik; jangan ramai-ramai; dengarkan suaraku; bersihkan tempatku; jangan mengganggu temanmu, dan sebagainya, yang terpenting dalam penyampaiannya harus diberikan secara tiba-tiba pada saat-saat yang diperlukan. ${ }^{17}$

\section{2) Taman Muda (umur 9-12 tahun)}

Menurut Ki Hadjar Dewantara pada anak-anak usia 9-12 tahun sudah masuk pada periode hakikat, yakni anak-anak sudah dapat mengetahui tentang hal baik dan buruk. Sehingga pengajaran karakter (budi pekerti) dapat di ajarkan melalui pemberian pengertian tentang segala tingkah-laku kebaikan dalam hidupnya sehari-hari. ${ }^{18}$

Didalam penyampainnya masih menggunakan metode occasional yaitu melalui pembiasaan dan divariasikan dengan metode hakikat dalam artian setiap anjuran atau perintah perlu di jelaskan mengenai maksud dan tujuan pendidikan karakter, yang pokok tujuannnya adalah mencapai rasa damai dalam hidup batinya, baik yang yang mengenai hidup dirinya sendiri maupun hidup masyarakatnya. Yang perlu diperhatikan dalam pengajaran ini menurut Ki Hadjar Dewantara bahwa anakanak dalam periode hakikat masih juga perlu melakukan pembiasaan seperti dalam periode syariat.

\section{3) Taman Dewasa (umur 14-16 tahun)}

Periode ini merupakan awal dimulainya materi yang lebih berat karena pada periode inilah anak-anak disamping meneruskan pencarian pengertian, mulai melatih diri terhadap segala laku yang sukar dan berat

17 . Ibid. h. 488.

18 . Ibid. h. 488. dengan niat yang disengaja. ${ }^{19}$

Pada periode ini juga, anak telah masuk pada periode "tarekat" yang dapat di wujudkan melalui kegiatan sosial, seperti pemberantasan buta huruf, pengumpulan uang, pakaian, makanan, bacaan-bacaan dan sebagainya untuk disedekahkan kepada orang-orang miskin atau orang-orang korban bencana alam dan sebagainya. Dan ketika pendidikan ini dilaksanakan di lingkungan perguruan muda (sekolah menengah atas) maka dapat dilaksanakan melalui pendidikan kesenian dan olahraga. Dan inti dari pengajaran pendidikan pada periode ini adalah semua laku (tidakan) yang disengaja yang memerlukan kekuatan kehendak (usaha) dan kekuatan tenaga (aplikasi).

4) Taman Madya dan Taman Guru (umur 1720)

Yaitu tempat pendidikan bagi anak-anak yang sudah benarbenar dewasa, pada periode inilah anak-anak telah memasuki periode ma'rifat yang artinya mereka telah dalam tingatan pemahaman. Yaitu biasa melakukan kebaikan, menginsyafi (menyadari) apa yang menjadi maksud dan tujuan. ${ }^{20}$ Pengajaran tentang karakter yang harus diberikan pada periode ini adalah berupa ilmu atau pengetahuan yang agak mendalam dan halus. Yaitu materi yang berkaitan dengan ethik dan hukum kesusilaan. Jadi bukan hanya berkenaan dengan kesusilaan saja melainkan juga tentang dasardasar kebangsaan, kemanusiaan, keagamaan, kebudayaan, adat istiadat dan sebagainya.

Melihat dari materi pendidikan karakter di atas dapat kita dipahami bahwa Ki Hadjar Dewantara menghendaki bahwa dalam penyampaian pendidikan karakter haruslah disesuaikan dengan umur si peserta didik. Tahapan tersebut disesuaikan dengan tingkatan psikologis methodis yang dikembangkan oleh Ki Hadjar Dewantara. Menurut penulis, dari materi pendidikan karakter di atas merupakan materi pendidikan operasional. Dengan kata lain materi tersebut merupakan cara untuk

19 . Ki Hajar Dewantara, Bagian I Pendidikan, Ibid. h. 488.

20 . Ibid., h. 489. 
meninternalisasikan nilai-nilai karakter. Materi yang sesungguhnya masih membutuhkan materi yang yang bersentuhan lansung dengan peserta didik.

\section{Konsep Pendidikan Karakter dalam perspektif pendidikan akhlaq dalam Islam}

\section{a. Hakikat Pendidikan Karakter dengan Pendidikan Akhlak}

Akhlaq menurut al-Ghazali bukanlah pengetahuan (ma'rifah) tentang baik dan jahat maupun kodrat (qudrah) untuk baik dan buruk, bukan pula pengamalan (fi'il), yang baik dan jelek, melainkan suatu keadaan jiwa yang mantap (hay'a rasikha fi-n-nafs). Akhlaq menurut al-Ghazali adalah "suatu kemantapan jiwa yang menghasilkan perbuatan atau pengamalan dengan mudah, tanpa harus direnungkan dan disengaja. Jika kemantapan itu sudah melekat kuat, sehingga menghasilkan amal-amal yang baik, maka ini disebut akhlaq yang baik. Jika amal-amal yang tercelalah yang muncul dari keadaan itu, maka itu dinamakan akhlaq yang buruk ${ }^{21}$

Namun walau demikian, pendidikan akhlak memiliki tujuan yang searah dengan pendidikan karakter. Jika tujuan pendidikan karakter adalah pada arah pengembangan potensi peserta didik, agar dapat menjadi individu yang siap menghadapi masa depan dan mampu survive mengatasi tantangan zaman dengan perilaku-perilaku yang terpuji, maka tak ubahnya tujuan pendidikan akhlak juga menginginkan terbangunnya perilaku-perilaku terpuji pada diri manusia.

Pendidikan karakter merupakan upaya penanaman nilai-nilai karakter pada peserta didik, baik nilai pengetahuan, kesadaran diri maupun tindakan, yang selanjutnya, peserta didik diharapkan dapat merealisasikan nilainilai tersebut terhadap Tuhan Yang Maha Esa, diri sendiri, sesama manusia, lingkungan maupun bangsa melalui sikap, perasaan, perkataan dan perbuatannya. Sehingga melalui

21 . M. Abul Quasem dan Kamil, Etika Al-Ghazali: Etika Majemuk di dalam Islam, terj. J. Mahyudin, (Bandung: Pustaka, 1988), hlm. 81- 82 pendidikan karakter, seorang anak akan menjadi cerdas intelegensinya dan juga emosionalnya.

Nilai pendidikan akhlak dalam merupakan serangkaian teori yang akan menjadi indah jika diterapkan dalam kehidupan. Kemudian berlanjut pada bentuk manifestasi akhlakakhlak tersebut. Demikian halnya dengan pendidikan karakter, dapat terlihat bahwa dalam pendidikan karakter juga mengandung unsur teori pengetahuan tentang sikapsikap terpuji (knowingthe good). Kemudian berlanjut pada feeling the good, agar seseorang dapatmerasakan dan mencintai kebaikan, dan setelah itu sampai pada tahap melakukan perbuatan tersebut (acting the good) yang kemudian akan menjadi suatu kebiasaan (habit).

Secara singkat dapat dikatakan bahwa nilai pendidikan akhlak dalam kitab terdapat relevansi dengan pendidikan karakter. Sebab, di dalamnya mengandung penanaman nilai-nilai karakter religius, disiplin,bertanggung jawab, bersahabat/komunikatif, cinta damai, toleransi, jujur, demokratis, menghargai prestasi dan peduli sosial. Nilai-nilai karakter tersebut cukup komprehensif, yakni learning to live together, learning to be dan hubungan dengan Tuhan. Dengan nilai-nilai tersebut, diharapkan setiap individu dapat memainkan perannya untuk menanamkan karakter baik, sehingga mampu mencapai totalitas kepribadian dan dapat survive untuk menjalani dan menghadapi tantangan masa depan Pendidikan karakter dianggap sebagai pendidikan nilai moralitas manusia yang disadari dan dilakukan dalam tindakan nyata. Tampak di sini terdapat unsur pembentukan nilai tersebut dan sikap yang didasari pada pengetahuan untuk melakukannya. Nilai-nilai itu merupakan nilai yang dapat membantu interaksi bersama orang lain secara lebih baik (learning to live together). Nilai tersebut mencakup berbagai bidang kehidupan, seperti hubungan dengan sesama (orang lain, keluarga), diri sendiri (learning to be), hidup bernegara, lingkungan dan Tuhan. ${ }^{22}$

22 . Masnur Muslih, Pendidikan Karakter Menjawab Tantangan Krisis Multidimensional

(Jakarta; Bumi Aksara, 2011), 67 


\section{A. Kesimpulan}

Pada bagian kesimpulan ini akan ditulis beberapa jawaban dari rumusan masalah yang telah ditentukan dalam bab pertama, penulis mengambil kesimpulan, yaitu:

Pertama, dalam pelaksanaan konsep pendidikan karakter Ki HadjarDewantara, menggunakan "Sistem Among" Dalam Sistem Among, maka setiap guru (pamong) sebagai pemimpin dalam proses pendidikan diwajibkan bersikap: Ing Ngarsa Sung Tuladha, Ing Madya Mangun Karsa, Tutwuri Handayani.

Kedua, Inti dari konsep Pendidikan akhlak dalam pendidikan Islam danpendidikan karakter mempunyai relevansi nilai-nilai yang terkait diantaranya adalah: Nilai pendidikan akhlak terhadap Allah, Nilai pendidikan akhlak terhadap diri sendiri, Nilai pendidikan akhlak terhadap orang lain.

\begin{tabular}{|c|c|}
\hline \multicolumn{2}{|c|}{$\begin{array}{l}\text { Persamaan konsep pendidikan karakter Ki Hajar Dewantara dan Pendidikan Akhlaq } \\
\text { dalam konsep Pendidikan Islam }\end{array}$} \\
\hline Pendidikan Islam & Ki Hadjar Dewantara \\
\hline $\begin{array}{l}\text { Etika sebagai seorang pendidik } \\
\text { Para pendidik selayaknya merupakan } \\
\text { manusia pilihan yang bukan hanya } \\
\text { memiliki kelebihan dari segi akademis } \\
\text { saja. Namun juga memiliki tanggung } \\
\text { jawab yang berat dalam melaksanakan } \\
\text { tugas dan fungsinya sebagai pendidik. } \\
\text { Para pendidik harus menguasai ilmu } \\
\text { dan mengajar anak didiknya dengan } \\
\text { profesional, sabar, telaten dan tertuju } \\
\text { pada pencapaian dunia dan akhirat. }\end{array}$ & $\begin{array}{l}\text { Ing Ngarsa Sung Tuladha, Seorang pamong } \\
\text { atau pendidik harus mampu memberikan } \\
\text { suri teladan bagi anak didiknya. } \\
\text { - Ing Madya Mangun Karsa, Seorang pamong } \\
\text { atau pendidik sebagai pemimpin hendakn- } \\
\text { ya mampumenumbuh-kembangkanminat, } \\
\text { hasrat dan kemauan anak didik untuk dapat } \\
\text { kreatif dan berkarya } \\
\text { Tutwuri Handayani. Seorang pendidik } \\
\text { adalah pemimpin yang harus memberikan } \\
\text { dorongan moral dan semangat kerja dari } \\
\text { belakang }\end{array}$ \\
\hline \multicolumn{2}{|c|}{$\begin{array}{c}\text { Perbedaan konsep pendidikan karakter Ki Hajar Dewantara dan Pendidikan Akhlaq } \\
\text { dalam konsep Pendidikan Islam }\end{array}$} \\
\hline Pendidikan Islam & Konsep Ki HadjarDewantara \\
\hline $\begin{array}{l}\text { 1. Akhlak seseorang harus memiliki niat } \\
\text { baik dalam mencari ilmu } \\
\text { 2. Mengingat Allah } \\
\text { 3. Menggunakan waktu dengan baik } \\
\text { 4. Akhlak pribadi untuk menjauhi larangan- } \\
\text { larangan Allah } \\
\text { 5. Etika sebagai seorang pendidik } \\
\text { 6. Akhlak peserta didik menjaga kesopanan } \\
\text { terhadap pendidik } \\
\text { 7. Menjaga etika terhadap orang tua } \\
\text { 8. Menjaga hubungan baik dengan orang } \\
\text { awam } \\
\text { 9. Menjaga hubungan baik dengan teman } \\
\text { dekat/sahabat } \\
\text { 10. Menjaga hubungan baik dengan orang yang } \\
\text { baru dikenal. }\end{array}$ & $\begin{array}{l}\text { - Taman Indria dan Taman Anak (5-8 tahun) } \\
\text { Pada tingkatan ini materi atau isi } \\
\text { pendidikan karakter (budi pekerti) berupa } \\
\text { pengajaran pembiasaan yang bersifat global } \\
\text { dan spontan atau occasional. } \\
\text { - Taman Muda (umur 9-12 tahun) } \\
\text { Pengajaran karakter (budipekerti) dapat } \\
\text { diajarkan melalui pemberian pengertian } \\
\text { tentang segala tingkah-laku kebaikan da- } \\
\text { lam hidupnya sehari-hari. } \\
\text { - Taman Dewasa (umur 14-16 tahun) } \\
\text { Periode ini merupakan awal dimulainya ma- } \\
\text { teri yang lebih berat karena pada periode } \\
\text { inilah anak-anak disamping meneruskan } \\
\text { pencarian pengertian, mulai melatih diri } \\
\text { terhadap segala laku yang sukar dan berat } \\
\text { dengan niat yang disengaja. } \\
\text { Taman Madya dan Taman Guru (umur 17- } \\
\text { 20) } \\
\text { Pengajaran tentang karakter yang harus } \\
\text { diberikan pada periode ini adalah berupa } \\
\text { ilmu atau pengetahuan yang agak menda- } \\
\text { lam dan halus. Yaitu materi yang berkaitan } \\
\text { dengan ethik dan hukum kesusilaan }\end{array}$ \\
\hline
\end{tabular}




\section{DAFTAR PUSTAKA}

Abdul majid, Dian andayani. 2010 Pedidikan karakter dalam perspektif Islam. Bandung: Insan Cita Utama.

Abidin Ibnu Rusn. 1998. Pemikiran al-Ghazali Tentang Pendidikan. Yogyakarta: Pustaka Pelajar.

Abu bakar, Muhammad. 1997. Hadits Tarbawi III. Surabaya: Karya Abditama.

Abu Hamid al-Ghazali. 1998. Tuntunan Mencapai Hidayah Ilahi, terj. M. Fadlil Sa'd An-Nadwi. Surabaya: AlHidayah.

Aminuddin, et al. 2006. Membangun Karakter dan Kepribadian Melalui Pendidikan AgamaIslam. Yogyakarta: Graha Ilmu.

Amin Syukur dan Masyharuddin, 2002. Intelektualisme Tasawuf. Yogyakarta: Pustaka Pelajar.

Anwar, Rosihan. 2010. Akhlak Tasawuf . Bandung: Pustaka Setia.

Anwar, Saeful. 2007. Filsafat Ilmu al-Ghazali Dimensi Ontologi dan Aksiologi. Bandung: Pustaka Setia.

Arikunto, Suharsimi.1996. ProsedurPenelitian. Jakarta: Rineke Cipta. Basri, Hasan. 2009. Filsafat Pendidikan Islam. Bandung: Pustaka Setia,

Basuki dan Miftahul Ulum, 2007. Pengantar Ilmu Pendidikan Islam. Ponorogo: Stain Po Press.

Beni Ahmad Saebani dan Abdul Hamid, 2010. Ilmu Akhlak. Bandung: Pustaka Setia. Daudy, Ahmad. 1986. Kuliah Filsafat Islam. Jakarta: Bulan Bintang.

D. Marimba. 1989. Pengantar Filsafat Pendidikan Islam. Bandung: AlMa'arif,

Dewantara, Ki Hadjar. 1962. Karya Bagian I: Pendidikan. Yogyakarta: Majelis Luhur Persatuan Taman Siswa.

Dewantara, Ki Hadjar, 1994. Bagian II : Kebudayaan.Yogjakarta : MLPTS.

FKI LIM. 2010. Gerbang Pesantren, Pengantar Memahami Ajaran
Ahlussunnah walJama'ah. Kediri: Bidang Penelitian dan Pengembangan LIM PP Lirboyo.

Gunawan, Heri. 2012. Pendidikan Karakter Konsep dan Implementasi. Bandung:Alfabeta. Irna H.N. Hadi Soewito. 1985. Soewardi Soerjaningrat dalam Pengasingan. Jakarta: Balai Pustaka.

Kesuma, Dharma, et.al. 2011. Pendidikan Karakter Kajian Teori dan Praktik di Sekolah. Bandung: Remaja Rosdakarya.

Khan, Yahya. 2010. Pendidikan Karakter Berbasis Potensi Diri: Mendongkrak KualitasPendidikan. Yogyakarta: Pelangi Publishing.

Ki Hariyadi, 1989. Ki Hadjar Dewantara sebagai Pendidik, Budayawan, PemimpinRakyatdalamBukuKiHadjar Dewantara dalam Pandangan Para Cantrik dan Mentriknya,Yogyakarta: MLTS,

Ki Suratman, 1987. Pokok-pokok Ketamansiswaan. Yogyakarta: MLPTS.

Koesoema A, Doni. 2010. Pendidikan Karakter Strategi Mendidik Anak di Zaman Global. Jakarta: PT.Grasindo.

Lickona, Thomas. 2004. Pendidikan Karakter. Bantul: Kreasi Wacana.

M. Ahmad, dkk. 1998. Pengembangan Kurikulum.Bandung : Pustaka Setia. Muhajir, Noeng. 1996. Metodologi Penelitian Filsafat.Yogyakarta : Rake Sarasin.

Muslih, Masnur. 2011. Pendidikan Karakter Menjawab Tantangan Krisis Multidimensional Jakarta; Bumi Aksara.

Mochtar Buchori, Character Building dan Pendidikan Kita. Kompas

M. Abul Quasem dan Kamil, 1988. Etika AlGhazali: Etika Majemuk di dalam Islam, terj. J.Mahyudin. Bandung: Pustaka. 
Nata, Abuddin. 2003. Pemikiran Para Tokoh Pendidikan Islam. Jakarta: Raja Grafindo Persada.

Nazir. 1998. Metode penelitian. Jakarta : Ghalia Indah.

Salahudin, Anas dan Alkrienciehie, Irwanto. 2013. Pendidikan Karakter: PendidikanBerbasis Agama dan Budaya Bangsa. Bandung: CV Pustaka Setia

Soeratman, Darsiti. 1983/1984. Ki Hadjar Dewantara, Jakarta. Departemen dan Kebudayaan.

Sudarto. 2001. Metodologi Penelitian Filsafat. Jakarta : Raja Grafindo.

Sudirman N. 1987. Ilmu Pendidikan. Bandung: Remaja Rosdakarya.

Sugiyono. 2009. Metode Penelitian Pendidikan Pendekatan Kuantitatif Kualitatif dan $R \& D$. Bandung : Alfabeta,

Tafsir, Ahmad. 1994. Filsafat Umum. Bandung : Remaja Rosda Karya, Cet.VII.

Tafsir, Ahmad. 2005. Ilmu Pendidikan dalam Perspektif Islam. Bandung: PT Remaja Rosdakarya.

Tauhid, Moch. 1963. Perjuangan dan ajaran Hidup Ki Hadjar Dewantara. Yogyakarta, MLPTS.

UU RI Tahun 2005 tentang Guru dan Dosen serta UU RI No. 20 Tahun 2003 tentang Sisdiknas.

Wibowo, Agus. 2013. Pendidikan Karakter Berbasis Sastra.Yogyakarta: Pustaka Pelajar.

Yamin , Moh. 2009. Menggugat Pendidikan Indonesia : Belajar dari Paulo Freire dan KiHajar Dewantara. Jogjakarta : Ar Ruzz Media.

Yudi Prahara, Erwin. 2009. Materi Pendidikan Agama Islam. Ponorogo: STAIN Po Press.

Departemen Agama RI. 2008. Al-Qur'andan Terjemahan Surat Al- Baqarah:2. Bandung: Diponegoro.

http://s4h4.wordpress.com/2008/11/30/ biografi-imam-ghazali/ http://syafieh. blogspot.com/2013/04/filsafat-islamal-ghazali-dan-pemikiran.html

Haryanto, Pendidikan Karakter Menurut Ki HadjarDewantara,(haryan62@yahoo. co.id). Diakses pada tanggal 29 Agustus 2016. http://www.ispi.or.id/2016/8/22/ mendalami-filsafat-pendidikan-kihajar-dewantara/ di akses pada 30 Agustus 2016 http://aryforniawan. blogspot.com/2016/08/fungsi-dantujuan-pendidikan-karakter.html Marfu. Perbedaan pendidikan karakter dengan pendidikan akhlak, pendidikan moral, danpendidikan nilai, http:// risetpendidikangmarfu'.com, Diakses pada tanggal 28 Agustus 2016.

Ni'matulloh.et. all, Pendidikan Karakter Dalam Persfektif Pendidikan Islam, (http:// nimatlloh. blogspot.com, diakses pada tanggal 20 Mei 2016)

Siswanto, Perbedaan pendidikan karakter dengan pendidikan akhlak, pendidikan moral, danpendidikan nilai, http:// siswantozheis.wordpress.com. Diakses tanggal 04 Juli 2016. 